\title{
The Role of Educational Counselors in Developing Students' Acceptance of Online Learning during COVID 19 Pandemic in Jordan: Educational Counselors and Students' Acceptance of online Learning
}

\author{
Omar Soud AlKhamaiseh \\ Assistant Professor in Counseling, \\ Al-Balqa Applied University, \\ The Hashemite Kingdom of Jordan
}

DOI: https://doi.org/10.36941/jesr-2021-0048

\section{Abstract}

This study aimed at examining the role of educational counsellors in helping students accept distance learning through the international pandemic of COVID 19 and the quarantine which many countries have to process on its population through closing universities, schools and academic institutions. The study adopted the basics of educational counselling which included (Individual Differences, Gender Differences, Growth Needs, Social Basics and Neurological and Physiological Abilities). Depending on the quantitative approach and using a questionnaire; (150) educational counsellors responded to the questionnaire and SPSS 21st Ed was used to screen and analyze the gathered data. Results of the study showed an influence of educational counsellors' role in helping students accept online learning, among used variables in the study; it appeared that minding gender difference between male and female students was the most influential compared to other variables. The study recommended promoting tasks and priorities of academic counselling in all schools, particularly government schools, and developing a culture that supports distance education and creates a positive electronic environment.

Keywords: Educational Counseling, Distance Learning, Technology Acceptance, COVID 19, Pandemic

\section{Introduction}

Guidance and counseling was not immune to practice since ancient times. Parents and teachers, for example, seek to help their children and students for their safety, maturity, and support of their capabilities, but this issue took the form of guidance only, without entering into an interactive relationship between the mentor and the individual in need of guidance, as the guidance is not sufficient to help the individual in achieving themselves, which increased the urgency of the need for a psychological counseling process that includes the face-to-face relationship between the mentor and the mentor. Then an indicative psychology phase emerged that focused on mental health and psychological development (Ilmiyah and Setiawan, 2020).

Educational guidance has an important and vital role in the educational process in the curriculum, and the educational counselor has multiple tasks that he performs that are no less important than the role of the teacher in the school, but complement each other (Liu et al, 2020). 
Basilaia and Kvavadze (2020) indicates that the impact of the Corona pandemic on education was disastrous due to the closure of schools and the attempt to deliver a distance education service during the quarantine period to avoid the spread of the epidemic. This has led to the distance of students, teaching staff, and vocational personnel and specialists in the field from their business locations. The most affected of this dimension were teachers and academic advisors.

Bozkurt and Sharma (2020) believes that the role of the academic advisor is as important as the teacher himself, as the academic advisor is the first assistant in understanding students and guiding them towards the mechanism of dealing with the school environment and understanding the differences between them in terms of mental, intellectual, emotional and physiological. This matter, according to Halstead et al (2013), highlights the role that the academic advisor played during the pandemic period, and how the mechanism was that was dealt with the students in order for the academic advisory service to continue to reach them.

On the other hand, Toquero (2020) stated that the academic advisor can do their entire role from a distance by following the students and guiding them and examining the problems they face during distance education, including dealing with the same idea.

Based on the above mentioned, current study seeks to examine the influence of educational counselor role through COVID19 pandemic on students' acceptance of distance learning after the lockdown of the country during the first half of 2020 .

\section{Literature Review}

\subsection{Counseling in Education}

Carlisle et al (2017) noted that the stages of age growth, transitional changes, family changes, the multiplicity of sources of knowledge and scientific disciplines, the development of the concept of education and its curricula, the increasing number of students, marriage problems, economic progress and the attendant anxiety and tension, all of which led to the emergence of the need for guidance and guidance, as this change in some Ideas and Trends Show the importance of guidance and counseling in the school in particular, as the teacher is no longer able to face this large number of burdens and changes as the changing roles and capabilities and the resulting conflicts and tension confirm the need for guidance and counseling programs.

Kozhabergenova et al (2018) defined educational counseling as the advisory services provided by the academic advisor - the faculty member - to develop the student cognitively, academically and professionally, and solve problems that hinder their academic achievement. Levitt et al (2015) noted that the educational counseling process is undertaken by a group of specialists at multiple levels in the administrative, supervisory and educational work. Haskins and Singh (2015) saw that an important task of the educational process is student counseling, which is often close to the student to assist and guide him. Therefore, whoever does this work must have a great degree of professional competence in helping the student to overcome any difficulties that he may encounter and directing him to be distinguished in his studies.

\subsection{Definition of Educational Counseling (Guidance)}

According to Young and Bryan (2015), educational counseling (guidance) is a set of tools, practices and theories which are aimed to help the student discover their academic abilities and capabilities, and to assist them in designing their study plan and selection for appropriate branching, and to achieve the requirements for graduation requirements and to help them overcome any difficulties that may impede their academic course, and also help them to adapt to their study environment, social and scientific environment by providing them with sufficient information. 


\subsection{The Role of Educational Counseling in Managing Students' Attitudes and Behavior}

According to Lerma et al (2015), educational counseling is a professional relationship that manifests itself in the assistance provided from one individual to another, an individual who needs help (the mentor) and another who has the ability to assist (the mentor) (Koltz et al, 2017). Realizing their abilities in a way that gives them compatibility and mental health; educational counseling is able to pushes individuals (students) to more growth and productivity, and adopting this professional relationship (face to face relationship) between the mentor and the student in a special place that guarantees the confidentiality of the mentor's conversations (Anastasov and Ristevska, 2019).

From another perspective, counseling is a preventive, developmental, and therapeutic process that requires specialization, preparation, efficiency, skill, and special characteristics that help the mentor to learn, make decisions, self-confidence, and develop motivation towards achievement. The educational guidance and guidance aims to achieve comprehensive growth for the student. To solve its problems, document the relationship between home and school, and change the student's behavior for the better under the umbrella of psychological counseling, and this in turn leads to achieving the goal towards improving the educational process (White and Levers, 2016).

\subsection{The Reality of Educational Counseling in Jordan}

The concept of psychological and educational counseling in Jordanian schools affiliated to the Ministry of Education is one of the most important fields that the Ministry has adopted for decades. Until 2020, the Ministry appointed (150) psychological counselors within a short period of time for every (250) students or more in school, whereas previously the ratio was one psychological counselor for every (275) students in the school. The ministry explained that in 2019 the ratio was a guide for every (300) students in each school, to drop in 2020 to (275) students, down to the ratio of (250) students in the next academic year 2019-2020, according to the ministry's website, where it indicated that the appointment process In this position, the campaign includes a specialization in educational counseling as well as psychology (MoE, 2020).

This is among the efforts of the Ministry of Education and its awareness of the need to activate the guiding side and focus on the psychological impact in particular, as it should give priority to school students to determine the psychological aspects and their motivations, whether negative or positive and taking into account the need to activate the role of the teacher in the classroom on familiarity with psychological and social aspects For the student and consider the personality of the student at this stage (Ghaith et al, 2012).

In Jordan, the educational process as a whole is based on the nature and composition of the human psyche and its ability to accommodate all that is new, but sometimes the student falls into the pain of the disparity between the school and home environment and the difference of views, which generates the student an aggressive or extremist tendency. This is confirmed in a report by ministry of education (2018) when indicated that the process of psychological and social counseling in terms of scientific definition meets at one point, which is the interest of the student in the first place and the development of the human soul that is always looking for the best.

On the other hand, Elliott et al (2019) indicated that the educational staff is concerned with forming the student's personality and taking into account the psychological and social conditions, indicating that most of the psychological problems that the student goes through in the stage of study, whether primary or secondary, are formed from the family environment and treat some teachers who insist on using the means Traditional education. From that point of view Haskins and Singh (2015) affirmed that the teacher inside the classroom has a great impact in terms of his dealings with the students of the class, such as siding with students without others or following the language of reprimand or cruelty, or dealing with soft and excessive positivity, which leads to the need to take care of the psychology of students.

As for Van Manen (2016), he emphasized that the joint cooperation between the school and the 
family has a great role in solving the problems facing students and contributes to creating an appropriate environment for refining the talents and orientations of students in the context of their desires without pressure on their feelings that often lead to psychological problems. On the other hand, Zhu (2018) pointed out that the most prominent problems experienced by students in government schools, from the basic stage to the secondary, are the difficulty of psychological and social adaptation to the school environment in addition to the phenomenon of bullying, which aims to weigh on the quality of education and student outcomes, which causes the formation of a phenomenon aggressiveness among students.

As for Hutchison et al (2016), he indicated through his study that the student's failure to know his life skills and inclinations leads to the psychological excitement of the student in an extreme way that was rebellious or separate from others, noting the problem of hyperactivity among some students that contributes to distracting the student's attention and causes a lack of motivation towards learning. While Wilkinson and Hanna (2016) found that the psychological counselor's role contributes to solving the family and social problems resulting in the deteriorating economic conditions, which led some to resort to immoral options at a time when the researcher pointed to the motives of jealousy, hatred and deprivation that contribute to creating a chaotic situation in the student's psyche and thus effect On his academic achievement and causing his lack of commitment to school time and delay in going to school. Accordingly, the role of the psychological counselor comes to resolving disputes and setting up a systematic plan to solve those crises that surround the student.

In general, there is awareness at the Jordanian Ministry of Education that the need for a psychological counselor helps in solving many psychological and behavioral problems suffered by school students, but the degree of suffering varies according to the school, the environment, the community and the nature of its training.

\subsection{Distance Learning}

According to Simpson (2018), there is no single definition of distance education as the definition can include the term online education using a personal computer or the term e-learning. In general, distance education depends on connecting to the Internet through interaction through forums and learning platforms, and educational courses are divided into units that contain videos and reading materials that provide the information the student needs to complete the assignments. Al Ghamdi et al (2016) defined distance learning as the state where education and learning can be accessed all over the world through the mean of internet; students who have access to a computer and access the Internet can obtain a certificate online and choose between a set of forms and educational programs that suit their lifestyle. While Krämer et al (2015) defined the concept of distance learning as the process of separating the learner, teacher and writers in the education environment, and transferring the traditional environment of education from a university or school and others to a multi-geographically separate environment, which is a modern phenomenon of education that has evolved with the accelerating technological development in the world, and its aim is to give the opportunity of education and provide it to students who cannot obtain it in circumstances Traditional and almost daily.

\subsection{Development of Distance Learning}

Siemens et al (2015) stated that the development of distance learning is traced back to the late 7os when European and American educational institutions were sending various education materials to the student by mail and included books, registration tapes, and video tapes to explain and teach the material, and in the same style the student was dealing with homework from home, with the requirement of these educational institutions that students are required to come to the university or school on the date of the final examination only for which the mark is calculated. In the late 8os, the idea of distance learning developed to become a communication between the teacher and students through television and radio stations, then with the advent of the Internet, email became the means of 
communication between the student and the teacher until the beginning of the new century, so there are specialized websites in this field, where they facilitated the process of communication and learning and provided seminars and direct contacts through the sites and programs specialized in it.

\subsection{The Philosophy of Distance Learning}

Kentnor (2015) argued that distance learning is based on a philosophy where there is a need for the availability of the Internet to communicate through it, as well as Lytvyn et al (2016) who argued that there is also a need for the virtual presence of the student or learner who tracks everything related to the educational material through specially designed programmed sites according to an appropriate mechanism to explain the material in a way that is easy to understand and benefit from, also Skorikova et al (2016) confirmed that direct and indirect discussion forums can be available between the student and the teacher, and finally, the teacher responsible for monitoring and evaluating the student's performance must be available and the marks that they deserve.

\subsection{Distance Learning During COVID 19 Pandemic}

There is no doubt that there are serious damage that the Corona virus has inflicted on the world economy, except for the severe damage that the virus has inflicted on all human societies, including the panic that the virus has spread among human beings everywhere on the planet, and the losses that the virus has caused to human health.

According to a report by WHO (2020), Virus Corona had some positives, including the role that he played in directing the distance education project from the drawers to the practical application in many schools and universities, where schools and university colleges gave virtual lectures and enabled students to follow Lectures in their homes via computers. Without this epidemic, educational and educational institutions would not have practiced distance education with this richness.

Distance education is one of the modern learning methods, and it mainly depends on the teacher giving his lectures from the virtual classroom. Students receive the lecture while they are at home, in their clubs, in their cities, or anywhere in the world. The virtual class opens to everyone for interactive discussion and quarterly participation in a way it benefits all students from anywhere in the world (Chick et al, 2020). In addition to that, authors argued that distance Learning is one of the outcomes of modern cognitive education, and indicators of knowledge education confirm that distance education will achieve more spread in all parts of the world, and it will have the main position in the education system and enlightenment everywhere in the world, and the need for distance education increases in circumstances Emergencies are such conditions in the world today because of the spread of the Corona virus.

The Corona pandemic prompted all countries to resort to using remote education means to achieve social exclusion. Jordan and Jordanians responded to the compliance with all their efforts to the wise royal approach, which emphasized the perpetuation of the educational process for students, and the preservation of students 'health at the same time, so education was In Jordan, various educational institutions rushed to e-learning and its platforms or distance education in order not to neglect and maintain the educational process and to keep the education wheel continuing in its rotation, where many successive decisions were issued in cooperation with all the concerned authorities by activating Defense Order No. (7) which has not neglected the educational process in order to ensure its continuity and enable it to rely on non-traditional educational methods, emerging platforms and modern electronic means and from its date, and the issuance of the Council of Ministers Resolution dated 15/4/2020, which stipulated: "for educational institutions operating in the Kingdom in accordance with the provisions of the Education Act: Adoption of non-traditional methods and methods of education, and the various forms of evaluation of student achievement that are carried out by electronic means, or distance education as accepted and approved methods and methods in all governmental and private educational institutions, within the Kingdom only and for the current school year 2019 / 2020, and 
thus the Jordanian state has taken the necessary legal measures to deal with the educational file during this pandemic by all parties involved in the educational process" (Al-Tamimi, 2020).

\section{Methods and Methodology}

\subsection{Model of the Study}

Following figure highlights the relationship between chosen variables of study:

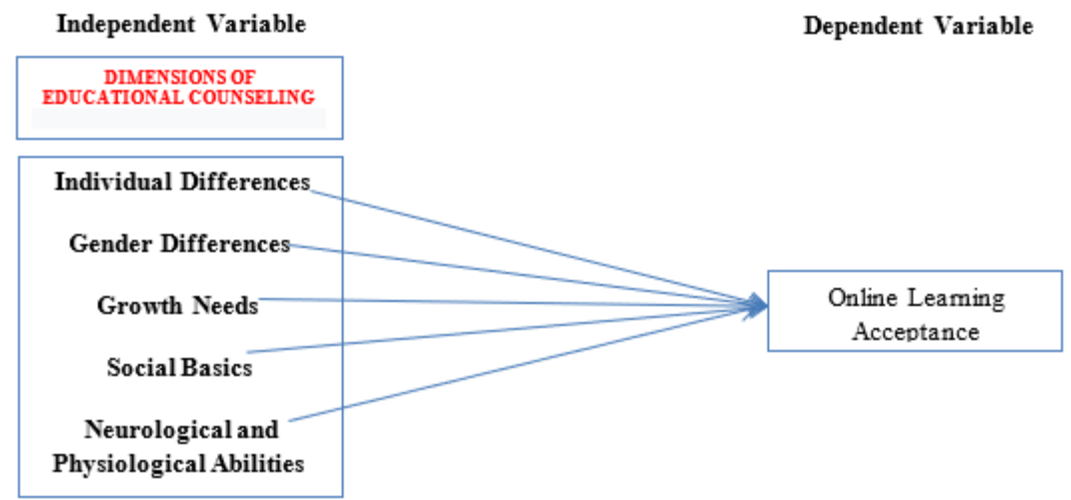

Figure (1): Study Model

Source: American School Counselor Association, 2017; Mullen et al., 2015

\subsection{Hypotheses of the Study}

From above model, following hypotheses were developed:

Ho: There is no statistically significant influence of dimensions of educational counseling on the level of students' acceptance of distance learning during the pandemic

$\mathrm{Ho}_{1}$ : There is no statistically significant influence of individual differences on students' acceptance of distance learning during the pandemic

According to Boeldt et al (2015), individual differences are a general principle and law, and individuals differ in quantity, quality, and wide-scale, and it appears in all aspects of personality, physically, mentally, socially, and emotionally. There are no known equations that apply to all individuals in the mentoring process. Sung et al (2016) stated that everyone has their own world and unique personality, distinct from other individuals, and they have their needs, capabilities and inclinations. It differs from everyone else because of its inherited characteristics and acquired characteristics, and there are no two on the face of the earth, one true copy. Even identical twins that originate from a single egg with a single start in growth from all manifestations quickly differ due to the multiple environmental factors that influence growth. So, an educational counselor should put into perspective those individuals' differences in dealing with students in order to guarantee the best and most accurate results from them.

$\mathrm{Ho}_{2}$ : There is no statistically significant influence of gender differences on students' acceptance of distance learning during the pandemic

Physiological, physical, social, mental and emotional differences are one of the most important axes of educational guidance, and education plays an important role in highlighting the gender differences in the social roles that it plays as individuals of both sexes, and it is sufficient to represent on that some special differences in capabilities, attitudes, tendencies and social standards related to 
clothing and available work (Balkis and Erdinç, 2017). Gnilka and Novakovic (2017) believed that psychological masculinity or psychological femininity is multiple in light of whether the individual's behavior is more inclined towards male behavior or towards female behavior regardless of his gender vital. Femininity / masculinity are an important component of the psychological counseling and guidance process. As what applies to females does not apply to males (Sung et al, 2015).

$\mathrm{Ho}_{3}$ : There is no statistically significant influence of growth needs on students' acceptance of distance learning during the pandemic

Psychological counseling contributes to knowing the growth demands and the criteria that it refers to in assessing the growth of the individual, whether it is normal, unusual, advanced or late. It focuses on self-growth and self-realization (Smith and Koltz, 2015). Psychological counseling and growth psychology share an interest in caring for normal growth in all its physical, mental, social, and emotional manifestations in successive stages of development. Psychological counseling emphasizes the importance of helping an individual achieve psychological maturity, which is a common goal with growth psychology. Also, the counseling process is a continuous process from incubation to old age (Menon et al, 2016).

$\mathrm{Ho}_{4}$ : There is no statistically significant influence of social basics on students' acceptance of distance learning during the pandemic

The social basics are one of the most important things that educational counseling is interested in (Tarrasch, 2015). It takes into account that the growth of individuals and their movement within the different age stages starting from childhood through adolescence and adulthood may lead to weakness and lack of concern of the family with individuals and thus deviating their path from the correct foundations as they enter into multiple labyrinths of academic failure, moral deviance, and the destruction of cultural identity (Dong et al, 2015).

The importance of social basics within the idea of study revolves around the role of social counseling in re-introducing parents to the circle of education of their children and integrating them into education requirements and problems that would confront the student and cause their failure to study (Nassar and Singh, 2020). In addition to that, educational counseling is able to integrate the individual into a circle of family, friends, and teachers that can correct their path and support them to reach their goals (Yamamoto, 2018).

$\mathrm{Ho}_{5}$ : There is no statistically significant influence of Neurological and Physiological Abilities on students' acceptance of distance learning during the pandemic.

Usually, the educational counselor is fully aware that the human behaves in his environmental surroundings as a physical psychological unit, the psychological state is affected by the physical condition - and the opposite is true - in a balance under the normal conditions of a compatible normal personality. The body is considered to be a mediator between the external environment and the self as a psychological entity, and the severe chronic emotional stress and personality disorder lead to this balance being disturbed (Hardell, 2018).

In that sense, an educational counselor is aware that there is an undeniable connection between the soul and the body, and this association has an effect on emotional and physiological processes, that is, on the functions of the body's organs. The role of a counselor is in gaining the needed information regarding the neurological and physiological needs of students in order to help them achieve their goals and accept new ideas, tools, means and approaches within exceptional times (Almojaibel, 2017).

\subsection{Research Instrument}

In order to realize hypotheses of current study; researcher adopted the quantitative approach through utilizing a questionnaire which was distributed on total of (163) academic counseling within capital of Jordan, Amman. The questionnaire was built by researcher with the help of previous studies and articles which tackled the same concept of pandemics influence on counseling activities and distance learning. The questionnaire appeared in two main sections; the first took into perspective demographics of study sample which included (gender, age, qualification, and experience in academic counseling field); while the other section presented statements related to variables of study (Individual 
Differences, Gender Differences, Growth Needs, Social Basics and Neurological and Physiological Abilities). Population of study consisted of all educational counselors who were working under the umbrella of Jordanian ministry of education.

\subsection{Sample of the Study}

A sample of (163) educational counselor was chosen to realize the study hypotheses and be exposed to the questionnaire. The sample was reached through contacting the Jordanian ministry of education and Queen Rania Al-Abdullah foundation for educational excellence. After application process; total of (150) responded to the questionnaire giving an indication of a response ratio of $92 \%$ as statistically acceptable.

\subsection{Tool Validity}

Cronbach's Alpha was used to test the of study tool, it resulted in a value of (0.951) for all the items within the study; the alpha however resulted greater than 0.60 which indicated the tool consistency that enhanced its use in the study.

Processing and data screening was done depending on SPSS $21^{\text {st }}$ Ed. Researcher entered the gathered data on the software and the following tests were done:

- Descriptive Statistics

- Multiple Regression

\section{Results}

Current section presented results of SPSS analysis of gathered data through the questionnaire. This section appeared in two parts, the first presented demographics of sample while the other section presented responses to questionnaire statements as according to individuals' responses.

\subsection{Demographics}

Table 1: Sample characteristics according to gender

\begin{tabular}{|c|c|c|c|c|c|}
\hline $\begin{array}{c}\text { Cumulative Percent } \\
64.0\end{array}$ & $\begin{array}{c}\text { Valid Percent } \\
64.0\end{array}$ & $\begin{array}{c}\text { Percent } \\
64.0\end{array}$ & $\begin{array}{c}\text { Frequency } \\
96\end{array}$ & Female & Valid \\
\hline \multirow[t]{2}{*}{100.0} & 36.0 & 36.0 & 54 & Male & \\
\hline & 100.0 & 100.0 & 150 & Total & \\
\hline
\end{tabular}

As it can be seen from table (1), sample characteristics according to gender was calculated; results indicated that majority of sample was (female) with frequency of (96) forming (64\%) of total sample compared to (males) who appeared to form (36\%) of total sample with frequency of (54) individuals.

Table 2: Sample characteristics according to age

\begin{tabular}{|c|c|c|c|c|c|}
\hline Cumulative Percent & Valid Percent & Percent & Frequency & & \\
\hline $14 \cdot 7$ & $14 \cdot 7$ & $14 \cdot 7$ & 22 & $25-30$ & Valid \\
\hline 48.0 & $33 \cdot 3$ & $33 \cdot 3$ & 50 & $31-36$ & \\
\hline 76.0 & 28.0 & 28.0 & 42 & $37-42$ & \\
\hline $89 \cdot 3$ & $13 \cdot 3$ & $13 \cdot 3$ & 20 & $43-48$ & \\
\hline \multirow[t]{2}{*}{$95 \cdot 3$} & 10.7 & 10.7 & 16 & +49 & \\
\hline & 100.0 & 100.0 & 150 & Total & \\
\hline
\end{tabular}

Age results appeared in table (2) above, it was seen that majority of sample participated in study were within the age range of (31-36) forming (33.3\%) of total sample with frequency of (50), while least age 
range of respondents appeared to be $(+49)$ forming (10.7\%) of total sample.

Table 3: Sample characteristics according to academic qualification

\begin{tabular}{cccccc}
\hline \hline Cumulative Percent & Valid Percent & Percent & Frequency & & \\
1.3 & 1.3 & 1.3 & 2 & Diploma & Valid \\
64.0 & 62.7 & 62.7 & 94 & BA & MA \\
96.0 & 32.0 & 32.0 & 48 & PhD \\
100.0 & 4.0 & 4.0 & 6 & Total \\
\hline \hline
\end{tabular}

In table (3) above, sample characteristics according to qualifications was calculated; it appeared that majority of respondents held (BA) degree and formed (62\%) of total sample, (MA) holders formed $(32 \%)$ of sample and $(\mathrm{PhD})$ holders formed $(4 \%)$ of total sample.

Table 4: Sample characteristics according to experience in educational counseling

\begin{tabular}{cccccc}
\hline \hline Cumulative Percent & Valid Percent & Percent & Frequency & & Valid \\
20.7 & 20.7 & 20.7 & 31 & $2-4$ & $5-7$ \\
55.3 & 34.7 & 34.7 & 52 & $8-10$ \\
82.0 & 26.7 & 26.7 & 40 & $11-13$ \\
90.0 & 8.0 & 8.0 & 12 & +14 \\
100.0 & 10.0 & 10.0 & 15 & Total \\
& 100.0 & 100.0 & 150 & \\
\hline \hline
\end{tabular}

In order to classify respondents according to their years of experience, above (table4) indicated that majority of sample had an experience of (5-7) years forming $(34.7 \%)$ of total sample compared to least respondents with experience years of (11-13) who formed (8\%) of sample.

\subsection{Questionnaire Analysis}

In table (5) below, respondents' answers to the questionnaire statements were calculated; it was found out that all statements scored a mean higher than mean of scale (3.00) indicating a positive attitude from respondents towards presented statements. The positive attitudes also indicated a good level of awareness regarding educational counseling from participants which can be seen as a positive result.

Table 5: Analysis of questionnaire statements

\begin{tabular}{|c|c|c|c|c|}
\hline \multicolumn{5}{|c|}{$\begin{array}{l}\text { Std.Deviation Mean Maximum Minimum } \mathrm{N} \\
\text { Dimensions of Educational Counseling } \\
\text { Individual Differences }\end{array}$} \\
\hline 1.126 & 3.74 & 5 & 1 & $\begin{array}{l}\text { 150 Raise students' enthusiasm and motivation for distance learning, } \\
\text { and remind them of their success moments }\end{array}$ \\
\hline 1.248 & 3.69 & 5 & 1 & $\begin{array}{l}150 \text { Students are assured that distance education is a good way to } \\
\text { achieve their goals }\end{array}$ \\
\hline 1.045 & 3.71 & 5 & 1 & $\begin{array}{l}150 \text { Use suspense and attention-grabbing techniques to explain the } \\
\text { foundations of distance learning }\end{array}$ \\
\hline 1.140 & 3.61 & 5 & 1 & $\begin{array}{l}150 \text { Students' motivation has been strengthened using many methods } \\
\text { and tools }\end{array}$ \\
\hline 1.005 & $3 \cdot 59$ & 5 & 1 & 150 I avoid frustrating words in dealing with them \\
\hline 1.096 & 3.44 & 5 & 1 & $\begin{array}{l}150 \text { I instill in students the spirit of competition even if through } \\
\text { distance learning }\end{array}$ \\
\hline .979 & $3 \cdot 57$ & 5 & 1 & $\begin{array}{l}150 \text { I follow the achievement level of students in order to identify } \\
\text { distinguished and struggling students, and accordingly, I } \\
\text { communicate with students to solve their problems }\end{array}$ \\
\hline
\end{tabular}




\begin{tabular}{|c|c|c|c|c|}
\hline \multicolumn{5}{|c|}{ 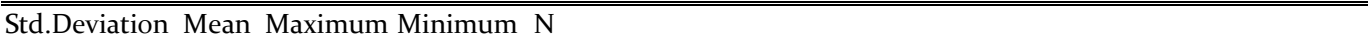 } \\
\hline .952 & 3.45 & 5 & 1 & $\begin{array}{l}150 \text { I follow up with the teacher to ensure planning for every work that } \\
\text { he does that is not repeated but rather constantly diversifies, in his } \\
\text { goals, content, means and methods, to take into account the } \\
\text { individual differences between students and meet their different } \\
\text { needs. }\end{array}$ \\
\hline .82890 & 3.6000 & 5.00 & 1.38 & $\begin{array}{l}150 \text { Individual Differences } \\
150 \text { Valid N (listwise) }\end{array}$ \\
\hline
\end{tabular}

Gender Differences

$.896 \quad 3.49$

51

.973

.74021

5.00

\section{Growth Needs}

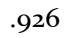

150 I guarantee that there are no differences in dealing between the sexes in relation to distance learning and that males and females take the same level of attention from the teaching staff and management

150 Ensure that males and females benefit from and complete the stages of education in addition to equally enhancing their capabilities in and through education

150 I try to focus on females in less fortunate regions

150 I receive complaints continuously all day from students or their families about any problems they encounter

150 I am dealing with situations that prevent females from receiving their classes remotely correctly including poverty, geographical isolation, disability, early marriage and pregnancy, gender-based violence

150 Gender equality was promoted in distance educational laws, policies and plans

150 I guarantee that there are no differences in dealing between the sexes in relation to distance learning and that males and females take the same level of attention from the teaching staff and management

150 Ensure that males and females benefit from and complete the stages of education in addition to equally enhancing their capabilities in and through education

150 I try to focus on females in less fortunate regions

150 I receive complaints continuously all day from students or their families about any problems they encounter

150 Gender Differences

150 Valid N (listwise)

150 I consider the availability of the tools for distance learning for each student and I am keen to find a solution for those who do not have the tools of distance learning such as the Internet, the computer, etc.

150 I monitor the situation of students in disadvantaged areas or students who are financially troubled in order to find solutions and assistive mechanisms

150 Students are encouraged to work in groups in order to motivate each other

150 I try to keep the distance learning classes out of boredom and routine

150 I try to remind students that distance learning is useful just as much as learning in the classroom and that current situations require their understanding of this

150 I consider the availability of the tools for distance learning for each student and I am keen to find a solution for those who do not have the tools of distance learning such as the Internet, the computer, etc.

150 Growth Needs 150 Valid N (listwise) 


\begin{tabular}{|c|c|c|c|c|}
\hline \multicolumn{5}{|c|}{ Std.Deviation Mean Maximum Minimum N } \\
\hline \multicolumn{5}{|c|}{ Social Basics } \\
\hline 1.123 & 3.80 & 5 & 1 & 150 Involve parents in matters related to distance study \\
\hline 1.255 & 3.74 & 5 & 1 & 150 I am trying to make parents part of the educational process \\
\hline 1.053 & 3.79 & 5 & 1 & $\begin{array}{l}150 \text { I follow the student's order through him and through } \\
\text { communication with the parents }\end{array}$ \\
\hline 1.167 & 3.67 & 5 & 1 & $\begin{array}{l}150 \text { Students are encouraged to communicate with each other for the } \\
\text { purpose of understanding the nature of distance education }\end{array}$ \\
\hline 1.043 & 3.65 & 5 & 1 & 150 Students are given realistic examples of past successes \\
\hline .92801 & 3.7307 & 5.00 & 1.00 & $\begin{array}{l}150 \text { Social Basics } \\
150 \text { Valid N (listwise) }\end{array}$ \\
\hline \multicolumn{5}{|c|}{ Neurological and Physiological Abilities } \\
\hline 1.115 & $3 \cdot 53$ & 5 & 1 & $\begin{array}{l}\text { 150 I guarantee that there is a balance between the scientific subject } \\
\text { and the time of the class }\end{array}$ \\
\hline .978 & 3.68 & 5 & 1 & $\begin{array}{l}\text { 150 I guarantee that there is a diversity of teaching methods and the } \\
\text { introduction of suspense }\end{array}$ \\
\hline .966 & 3.56 & 5 & 1 & 150 I encourage students to accept practical material \\
\hline .914 & $3 \cdot 58$ & 5 & 1 & $\begin{array}{l}150 \text { I take into account the students 'inclinations and their willingness } \\
\text { to accept the scientific subject outside the classroom }\end{array}$ \\
\hline 1.008 & $3 \cdot 51$ & 5 & 1 & 150 Ensure that there is a high preparedness for the next class \\
\hline .981 & 3.67 & 5 & 1 & $\begin{array}{l}150 \text { I communicate with the material teachers in order to review the } \\
\text { tests and ensure that they coincide with the presented scientific } \\
\text { material }\end{array}$ \\
\hline .981 & 3.76 & 5 & 1 & 150 I do flexibility with students \\
\hline .79447 & 3.6114 & 5.00 & 1.43 & $\begin{array}{l}150 \text { Neurological and Physiological Abilities } \\
150 \text { Valid N (listwise) }\end{array}$ \\
\hline
\end{tabular}

Table 6: Descriptive analysis of variables

\begin{tabular}{|c|c|c|c|c|}
\hline \multicolumn{5}{|c|}{ Reality of Online Learning (Distance) in Jordan During the Pandemic } \\
\hline \multicolumn{5}{|c|}{ Std.Deviation Mean Maximum Minimum N } \\
\hline 1.016 & 3.69 & 5 & 1 & $\begin{array}{l}150 \text { The Jordan Sports TV channel has been reconfigured to broadcast } \\
\text { educational programs specifically designed for students preparing } \\
\text { for the Tawjihi exam. }\end{array}$ \\
\hline 1.028 & 3.95 & 5 & 1 & $\begin{array}{l}150 \text { The Ministry of Education supported teachers by implementing } \\
\text { new interventions to facilitate the transition to distance learning. }\end{array}$ \\
\hline 1.019 & 3.71 & 5 & 1 & $\begin{array}{l}\text { 150 A newly launched teacher training platform that provides } \\
\text { training courses on distance learning tools, mixed learning, and } \\
\text { educational technology. }\end{array}$ \\
\hline 1.028 & 3.87 & 5 & 1 & $\begin{array}{l}\text { 150 Ministry of education in Jordan Urged parents to participate in } \\
\text { government efforts to ensure successful distance learning. }\end{array}$ \\
\hline .986 & 3.81 & 5 & 1 & $\begin{array}{l}150 \text { These timely measures helped to contain and mitigate the impact } \\
\text { of the pandemic on learning in Jordan. }\end{array}$ \\
\hline 1.019 & 3.91 & 5 & 1 & $\begin{array}{l}\text { 150 Jordanian government highlighted the importance of using } \\
\text { distance learning tools effectively while promoting equal access } \\
\text { to reduce the impact of disturbances. }\end{array}$ \\
\hline .935 & 3.72 & 5 & 1 & $\begin{array}{l}150 \text { Many children in Jordan have access to internet but } \\
\text { comprehensive access has yet to be achieved. }\end{array}$ \\
\hline \multirow[t]{2}{*}{.80674} & 3.808 & 5.00 & 1.00 & 150 REALITY \\
\hline & & & & 150 Valid N (listwise) \\
\hline
\end{tabular}

As for the following table (6), mean and standard deviation were calculated for total attitudes of answering variables' statements. There also appeared positive attitudes in that sense given that all variables' means scored higher than mean of scale 3.00 which indicated that statements were clear for participants and matched their level of understanding regarding the field of educational counseling. 


\subsection{Hypotheses Testing}

4.3.1 Ho: There is no statistically significant influence of dimensions of educational counseling on the level of students' acceptance of distance learning during the pandemic

Table 7: Ho Testing

\begin{tabular}{|c|c|c|c|c|c|c|}
\hline \multicolumn{7}{|c|}{ Model Summary } \\
\hline Std. Error of the Estimate & Adjusted R & Square & & R Square & $\mathrm{R}$ & Model \\
\hline .28133 & .878 & & & .882 & $.939^{\mathrm{a}}$ & 1 \\
\hline \multicolumn{7}{|c|}{ ANOVA } \\
\hline Sig. & $\mathrm{F}$ & Mean Square & df & Sum of Squares & Model & \\
\hline \multirow[t]{4}{*}{$.000^{\mathrm{a}}$} & 216.249 & 17.115 & 5 & 85.576 & Regression & 1 \\
\hline & & .079 & 144 & 11.397 & Residual & \\
\hline & & & 149 & 96.973 & Total & \\
\hline & & Coeffic & nts & & & \\
\hline \multirow{3}{*}{$\begin{array}{c}\text { Standardized Coefficients } \\
\text { Beta }\end{array}$} & \multicolumn{3}{|c|}{ Unstandardized Coefficients } & \multirow[t]{2}{*}{ Model } & & \\
\hline & Std. Error & & B & & & \\
\hline & .134 & & $-.249^{-}$ & \multicolumn{2}{|l|}{ (Constant) } & 1 \\
\hline$-1.001-$ & .076 & & $-.974-$ & \multicolumn{2}{|c|}{ Individual Differences } & \\
\hline .730 & .062 & & .795 & \multicolumn{2}{|c|}{ Gender Differences } & \\
\hline .230 & .049 & & .252 & \multicolumn{2}{|c|}{ Growth Needs } & \\
\hline .845 & .061 & & .734 & \multicolumn{2}{|c|}{ Social Basics } & \\
\hline .264 & .050 & & .268 & \multicolumn{2}{|c|}{$\begin{array}{l}\text { Neurological and Physiological } \\
\text { Abilities }\end{array}$} & \\
\hline
\end{tabular}

Based on results in table (7) and launching from multiple regression of hypothesis testing revealing that $\mathrm{F}$ value sored $0.939, \mathrm{~F}$ value significant at $\mathrm{P}$-Value $<0.05$ and referred to a correlation between dependent and independent variables; results indicated that the hypothesis was rejected and there appeared to be an influence of educational counseling dimensions on students' acceptance of online learning during the pandemic

4.3.2 $\mathrm{Ho}_{1}$ : There is no statistically significant influence of individual differences on students' acceptance of distance learning during the pandemic

Table 8: $\mathrm{Ho}_{1}$ Testing

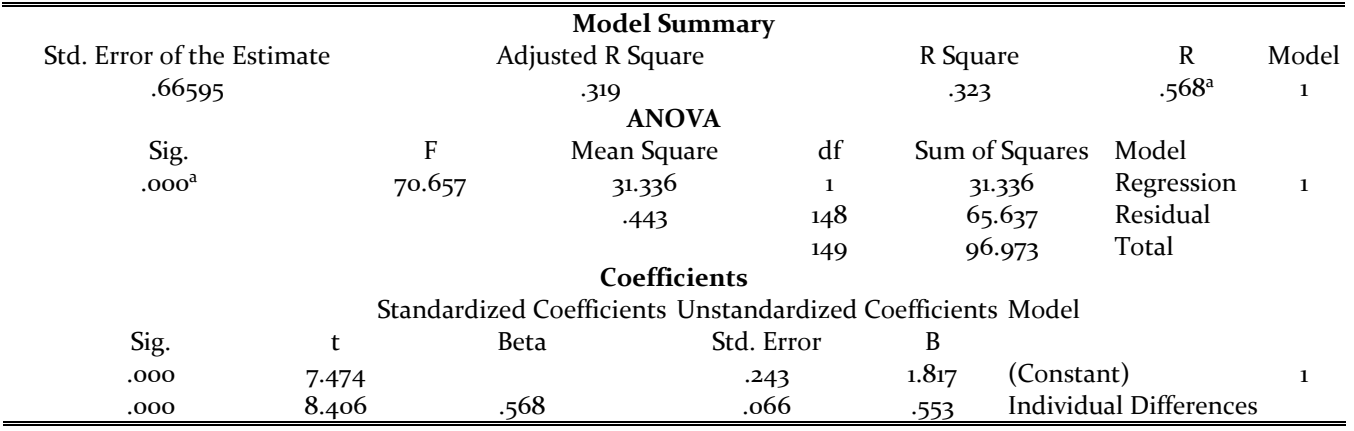

Examining table (8), linear regression was employed in order to test the above hypothesis, with an $\mathrm{R}$ value of 0.568 and $\mathrm{F}$ value significant at $\mathrm{P}$-Value $<0.05$, it was indicated that there is a correlation between independent and dependent variable leading to rejecting the $1^{\text {st }}$ sub-hypothesis and confirming the fact that minding individuals' difference by educational counselors helped students in 
accepting online learning during the pandemic.

4.3.3 $\mathrm{Ho}_{2}$ : There is no statistically significant influence of gender differences on students' acceptance of distance learning during the pandemic

Table 9: $\mathrm{Ho}_{2}$ Testing

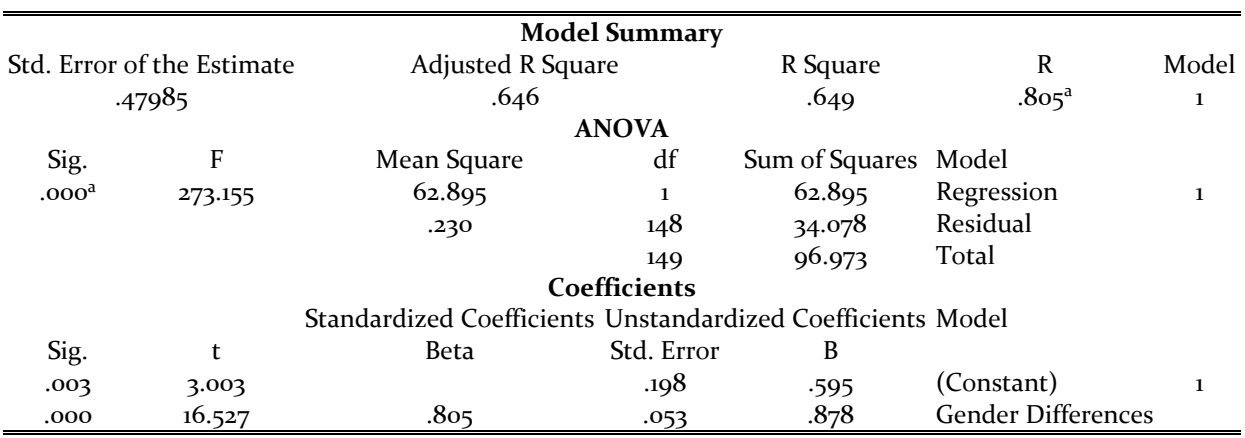

In $2^{\text {nd }}$ hypothesis testing above, linear regression analysis was used and referred that $\mathrm{R}$ value was 0.805 , also, F value significant at P-Value $<0.05$ this indicated that there is a correlation between dependent and independent variables and based on that; there is a positive influence of minding gender difference by counselors in a way that increased students' acceptance of online learning during the pandemic.

4.3.4 $\mathrm{Ho}_{3}$ : There is no statistically significant influence of growth needs on students' acceptance of distance learning during the pandemic

Table 10: $\mathrm{Ho}_{3}$ Testing

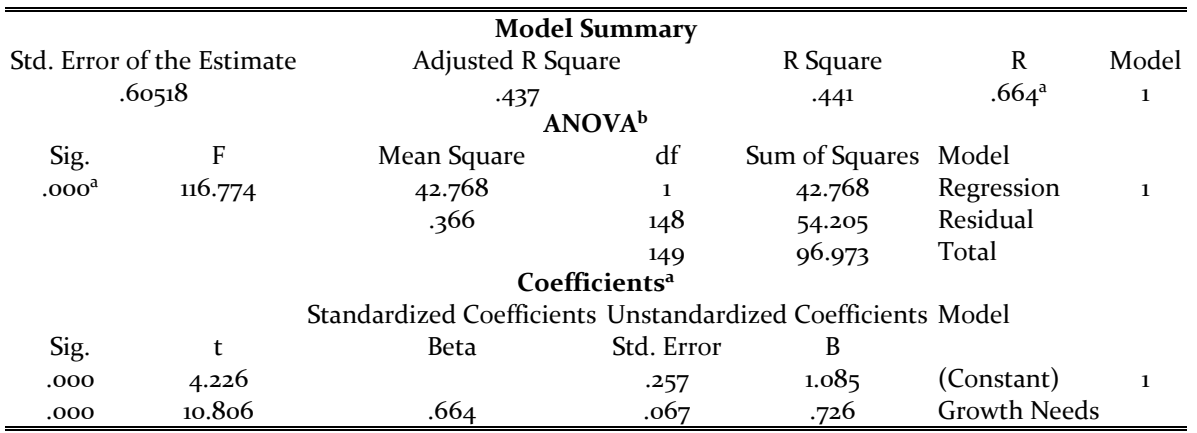

Table (10) showed results of using linear regression analysis to test $3^{\text {rd }}$ hypothesis. It was seen that $\mathrm{R}$ value scored 0.664 and $F$ value significant at $P$-Value $<0.05$ which indicated a relationship that positive between independent and dependent variables, this leads to rejecting the $3^{\text {rd }}$ hypothesis and confirming that there is a positive influence of minding growth needs on students' acceptance of online learning during the pandemic. 
4.3.5 $\mathrm{Ho}_{4}$ : There is no statistically significant influence of social basics on students' acceptance of distance learning during the pandemic

Table (11): $\mathrm{Ho}_{4}$ Testing

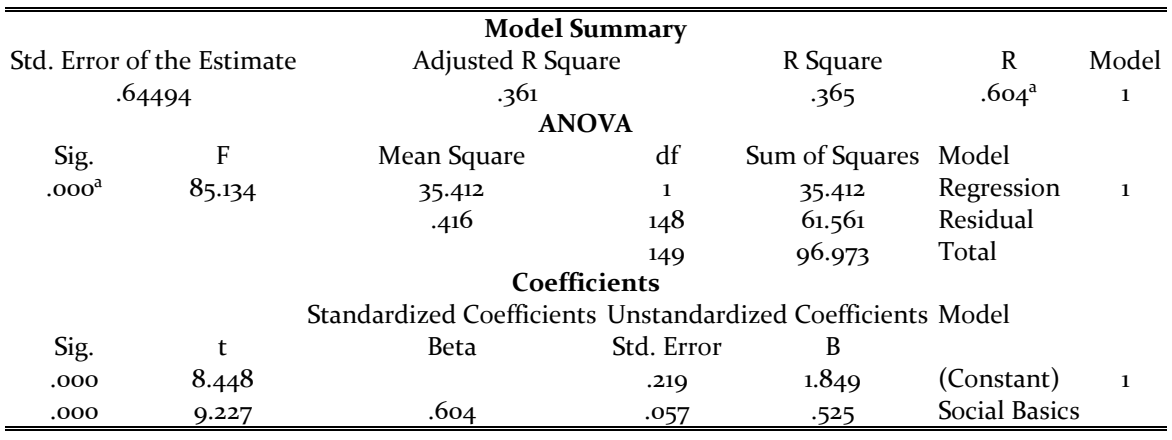

As it can be seen from table (11) above, linear regression analysis was used to identify the reality of $4^{\text {th }}$ hypothesis, an $\mathrm{R}$ value of 0.604 appeared and $\mathrm{F}$ value significant at P-Value $<0.05$ which rejected the original hypothesis and confirming a correlation between dependent and independent variables, this managed to assure that minding the social needs are among the factors that helped students to accept online learning during the pandemic in Jordan.

4.4 $\mathrm{Ho}_{5}$ : There is no statistically significant influence of Neurological and Physiological Abilities on students' acceptance of distance learning during the pandemic

Table 12: $\mathrm{Ho}_{5}$ Testing

\begin{tabular}{|c|c|c|c|c|c|c|}
\hline \multicolumn{7}{|c|}{ "Model Summary } \\
\hline Std. Error of the Estimate & \multicolumn{2}{|c|}{ Adjusted R Square } & \multicolumn{2}{|r|}{ R Square } & $\mathrm{R}$ & Model \\
\hline \multirow[t]{2}{*}{.52751} & \multicolumn{2}{|c|}{.572} & & .575 & $.758^{\mathrm{a}}$ & 1 \\
\hline & \multicolumn{3}{|c|}{ ANOVA } & & & \\
\hline \multirow{5}{*}{$\begin{array}{l}\text { Sig. } \\
.00 o^{a}\end{array}$} & \multirow{4}{*}{$\begin{array}{c}F \\
200.487\end{array}$} & Mean Square & df & Sum of Squares & Model & \\
\hline & & 55.789 & 1 & $55 \cdot 789$ & Regression & 1 \\
\hline & & .278 & 148 & 41.184 & Residual & \\
\hline & & & 149 & 96.973 & Total & \\
\hline & & Coefficient & & & & \\
\hline \multirow{3}{*}{$\begin{array}{c}\text { Standardized Coefficients } \\
\text { Beta }\end{array}$} & \multicolumn{3}{|c|}{ Unstandardized Coefficients } & \multirow[t]{2}{*}{ Model } & & \\
\hline & Std. Error & & B & & & \\
\hline & .201 & & 1.027 & \multirow{2}{*}{\multicolumn{2}{|c|}{$\begin{array}{l}\text { (Constant) } \\
\text { Neurological and } \\
\text { Physiological Abilities }\end{array}$}} & 1 \\
\hline .758 & .054 & & .770 & & & \\
\hline
\end{tabular}

In table (12), linear regression was used in order to test the $5^{\text {th }}$ hypothesis, it was seen that $\mathrm{R}$ value scored 0.758 which is an indication of the correlation between dependent and independent variables; with an $\mathrm{F}$ value significant at $\mathrm{P}$-Value $<0.05$, it was confirmed that the null hypothesis was rejected and that minding the neurological and physiological abilities of students helped them to accept online learning during the pandemic in Jordan.

\section{Discussion}

Current study aimed at examining the role of educational counselor in supporting students' 
educational journey through the online means during the COVID 19 pandemic and the lockdown that Jordan was exposed in the first half of 2020. Examining the influence of educational counselors came through measuring their focus on 5 main aspects of educational counseling which included (Individual Differences, Gender Differences, Growth Needs, Social Basics and Neurological and Physiological Abilities). Results were obtained through uploading a questionnaire online for the chosen sample of educational counselors obtained from contacting the Jordanian ministry of education.

Study results came up with the following results:

- There is a high level of awareness regarding educational counseling dimensions among participants as respondents' answers to the statements came with positive attitudes referring to their full knowledge of their duties.

- All statements were answered in a way that reflected the ability of respondents to manage their duties and present the best approach to educational counseling during exceptional situations.

- Majority of respondents answering questionnaire appeared to be (female) individuals within the age range of (31-36) holding (BA) degree in educational and psychological counseling with an experience of (5-11) years.

- All null hypotheses of study were rejected and there appeared to be a positive influence of educational counseling dimensions including (Individual Differences, Gender Differences, Growth Needs, Social Basics and Neurological and Physiological Abilities) on students' acceptance of online learning during COVID 19 pandemic an the quarantine in Jordan in 2020.

- Most influential variable of all study variables in effecting students' acceptance of online learning during the pandemic and lockdown in Jordan appeared to be gender differences scoring an $\mathrm{R}$ value of 0.805 and referring to the influence of minding gender differences (male/female) and its role in increasing the acceptance of online learning.

- The least influential variable of all appeared to be individual difference which scored an $\mathrm{R}$ value of 0.568 among all chosen variables; however, the variable still appeared to be influential on degree of students' acceptance of online learning.

It appeared through results that the main hypothesis of study was rejected and referred that educational counseling prove its efficiency in increasing the level of students' acceptance of online learning especially through the exceptional times of COVID 19 pandemic spread and the need to lockdown all the country including its educational institutions.

From study results, the variable of gender differences appeared to be the most influential in helping students accepting online learning, the gender differences appeared to be of great influence in managing the transitional approach of students from classroom teaching to online teaching through the virtual world. This result matched what came along with Balkis and Erdinç (2017) when they argued that there is no doubt of the need of an educational counselor to have the ability and the awareness regarding the gender differences between male and female students in educational setting. Also, the results matched what Gnilka and Novakovic (2017) brought up regarding the same idea and stated that the differences between genders may play a role in tackling change and managing it within a gender related situation, also Sung et al (2015) supported the same idea.

In the $2^{\text {nd }}$ rank of influence; there appeared that neurological and physiological abilities are influential in managing online learning acceptance of students as it sored a value of 0.758 and indicated that minding the neurological and physiological abilities of students in the setting of online learning. The same idea was tackled by Russell-Chapin (2016) who argued that neurological and physiological abilities of individuals differs in the way they handle activity, neurological aspects are more influential especially when it comes to technology and accepting it. Also, Barden et al (2015) referred to the role of abilities and its differences from one individual to another.

Growth needs variable appeared to be in the $3^{\text {rd }}$ rank scoring an $\mathrm{R}$ value of 0.664 and indicating that some of the activities among students are basically hard to achieve if the educational counselor didin't put into perspective their needs which rhymes with what Smith and Koltz (2015) and Menon et al (2016) noted. While on the $4^{\text {th }}$ rank the variable of social basics scored an $\mathrm{R}$ value of 0.604 and 
indicated that the lack of technology though growing up and the support from family and friends may hinder the students' ability to accept online learning.

The least influential variable appeared to be individual difference scoring an $\mathrm{R}$ value of 0.568 , this variable indicated that the individual's awareness of themselves and their awareness of the environment differs from the awareness of others as this awareness is affected by many factors, including level of growth, level of education, social class and the society in which they live. These results rhymed with what came along with Boeldt et al (2015) and Sung et al (2016) when they argued that what we see as an agreement in the general perception among individuals is due to the existence of similar common experience in general. Even the agreement is not complete, but it is close and it is this convergence that leads to understanding and agreement. Therefore, individual differences should be included in the calculation when performing the psychological guidance and counseling process, and there is no single guidance method that works for everyone.

Hence, the current study confirmed that we are in urgent need of educational counseling and educational specialists in various fields of life, whether they are religious, educational, health, security or sports. As the presence of the student counselor in schools achieves educational goals, and students create education that refines behavior, and provides them with balance in all aspects of life in order to become good members and contribute to building society.

In the case of the exceptional situations that forced the suspension of educational facilities, the educational counselors demonstrated their merit and importance in studying the problems facing students in distance education, and they worked hard to find appropriate solutions to these problems by following the academic achievement of students, encouraging the excelling, and studying The situation of students with poor achievement, knowing the reasons through mutual cooperation between school and home, and finding good solutions to achieve the goals of education.

The educational counselors work to discover students' weaknesses and abilities and develop those capabilities and invest them for the benefit of the individual and society, and guide students and provide them with educational and professional opportunities so that they are able to deal with the pressures of distance learning and adapt to the exceptional and new situations.

Jordan, with all its health, civil and security institutions and its wise leadership since the beginning of the Corona crisis, has managed to overcome many challenges and put a distinct imprint and plan a unique model in crisis management, and this has been through its reliance on specific strategies committed to its full and rapid application and the highest levels and standards of transparency in Dealing with the crisis and its data. One of the most prominent of these strategies was the revitalization of the role of the Crisis Cell in the country and the activation of the defense law, which enabled Jordan to control and distinguish greatly in this pandemic that ravages the world as a whole, as a model of success for the rest of the countries in this field.

\section{Conclusion}

According to the global monitoring of school closures due to the Corona pandemic issued by UNESCO (2020); it was revealed that most governments in the world have temporarily closed educational institutions, in an effort to stem the spread of the Covid-19 pandemic. This closure has affected almost $60 \%$ of the world's students across the country. Other countries have closed schools in some areas, affecting the education of millions of additional learners. UNESCO is working to provide support to countries to mitigate the immediate impact of school closures, in particular the impact of the most vulnerable and disadvantaged groups, and it seeks to facilitate the sustainability of education for all through distance learning.

Counseling and guidance in all different fields of life is an essential requirement, which is good behavior, and a noble work that has positive fruits in society, especially if the mentor has many good values and good attributes, combined with good awareness of sound and successful education methods in dealing with others and guiding them to goodness. The school is one of the building blocks of society, but rather an integral part of society, and it is an educational entity that combines science, education 
and guidance, in order to bring us good generations working and trained in life, and aims to help students to be their personalities, know their capabilities, and be able to solve their problems, and have psychological, educational, health.

Through the current study and after examine hypotheses and reached results; it is worth to mention that study came up with the following question for future studies:

"Did Virus Corona contribute to reshaping the educational process? Will the idea of virtual educational counseling be adopted through the internet in the future?"

\section{Recommendations}

Based on above discussion of results, current study recommended the following:

- Promote the tasks and priorities of academic counseling in all schools, particularly government schools

- Develop a culture that supports distance education and creates a positive electronic environment.

- Developing organizational programs for students, teachers, and educational counselors to provide them with the assistance they need.

\section{References}

Al Ghamdi, A., Samarji, A., \& Watt, A. (2016). Essential considerations in distance education in KSA: Teacher immediacy in a virtual teaching and learning environment. International Journal of Information and Education Technology, 6(1), 17 .

Almojaibel, A. (2017). Understanding intention to use telerehabilitation: applicability of the Technology Acceptance Model (TAM) (Doctoral dissertation).

Al-Tamimi, A. (2020). [Higher education in Jordan beyond the Corona virus challenges. Al-Ghad News]. Retrieved from https://alghad.com.

American School Counselor Association. (2017). The School Counselor and Virtual School Counseling, Report, American School Counselor Association.

Anastasov, B., \& Ristevska, M. (2019). The Role Of The Counselor In The Pedagogical Counseling Process. International Journal of Education TEACHER, 9(18), 54-59.

Balkis, M., \& Erdinç, D. U. R. U. (2017). Gender differences in the relationship between academic procrastination, satifaction with academic life and academic performance. Electronic Journal of Research in Educational Psychology, 15(1), 105-125.

Barden, S., Conley, A., \& Young, M. (2015). Integrating health and wellness in mental health counseling: Clinical, educational, and policy implications. Journal of mental health counseling, 37(2), 152-163.

Basilaia, G., \& Kvavadze, D. (2020). Transition to online education in schools during a SARS-CoV-2 coronavirus (COVID-19) pandemic in Georgia. Pedagogical Research, 5(4), 1-9.

Boeldt, D. L., Schork, N. J., Topol, E. J., \& Bloss, C. S. (2015). Influence of individual differences in disease perception on consumer response to direct-to-consumer genomic testing. Clinical genetics, 87(3), 225-232.

Bozkurt, A., \& Sharma, R. C. (2020). Emergency remote teaching in a time of global crisis due to CoronaVirus pandemic. Asian Journal of Distance Education, 15(1), 1-5.

Carlisle, R. M., Hays, D. G., Pribesh, S. L., \& Wood, C. T. (2017). Educational technology and distance supervision in counselor education. Counselor Education and Supervision, 56(1), 33-49.

Chick, R. C., Clifton, G. T., Peace, K. M., Propper, B. W., Hale, D. F., Alseidi, A. A., \& Vreeland, T. J. (2020). Using technology to maintain the education of residents during the COVID-19 pandemic. Journal of Surgical Education, 77(4), 729-732

Dong, S., Ethridge, G., Rodgers-Bonaccorsy, R., \& Oire, S. N. (2015). Assessing infusion of social justice in rehabilitation counselor education curriculum. Rehabilitation Research, Policy, and Education, 29(4), 406420.

Elliott, A., Salazar, B. M., Dennis, B. L., Bohecker, L., Nielson, T., LaMantia, K., \& Kleist, D. M. (2019). Pedagogical perspectives on counselor education: An autoethnographic experience of doctoral student development. The Qualitative Report, 24(4), 648-666. 
Ghaith, S., Banat, S., Hamad, G., \& Albadareen, G. (2012). Jordanian School Counselor Involvement in SchoolFamily-Community Partnerships. International Journal for the Advancement of Counseling, 34(4), $307-319$.

Gnilka, P. B., \& Novakovic, A. (2017). Gender differences in STEM students' perfectionism, career search self-efficacy, and perception of career barriers. Journal of Counseling E Development, 95(1), 56-66.

Halstead, M. E., McAvoy, K., Devore, C. D., Carl, R., Lee, M., \& Logan, K. (2013). Returning to learning following a concussion. Pediatrics, 132 (5), 948-957.

Hardell, L. (2018). Effects of mobile phones on children's and adolescents' health: A commentary. Child development, $89(1), 137-140$.

Haskins, N. H., \& Singh, A. (2015). Critical race theory and counselor education pedagogy: Creating equitable training. Counselor Education and Supervision, 54(4), 288-301.

Hutchison, B., Odegard-Koester, M., \& Koltz, R. (2016). Intentional Work Group Experiences: A Pedagogical Tool for Counselor Educators. The Journal of Counselor Preparation and Supervision, 8(1), 3.

Ilmiyah, S., \& Setiawan, A. R. (2020). Students' Worksheet for Distance Learning Based on Scientific Literacy in the Topic Coronavirus Disease 2019 (COVID-19).

Kentnor, H. E. (2015). Distance education and the evolution of online learning in the United States. Curriculum and teaching dialogue, $17(1), 21-34$.

Koltz, R. L., Smith, A., Tarabochia, D. S., \& Wathen, C. C. (2017). A pedagogical framework for counselor educators working with millennial students. The Journal of Counselor Preparation and Supervision, 9(1), 6.

Kozhabergenova, G. E., Bulatbayeva, A. A., Kabakova, M. P., \& Asanov, N. A. (2018). The stewardship of school counselor education in higher educational establishments. Opción: Revista de Ciencias Humanas y Sociales, (85), 386-414.

Krämer, B. J., Neugebauer, J., Magenheim, J., \& Huppertz, H. (2015). New ways of learning: Comparing the effectiveness of interactive online media in distance education with the E uropean textbook tradition. British Journal of Educational Technology, 46(5), 965-971.

Lerma, E., Zamarripa, M. X., Oliver, M., \& Cavazos Vela, J. (2015). Making our way through: Voices of Hispanic counselor educators. Counselor Education and Supervision, 54(3), 162-175.

Levitt, D. H., Farry, T. J., \& Mazzarella, J. R. (2015). Counselor ethical reasoning: Decision-making practice versus theory. Counseling and Values, 6o(1), 84-99.

Liu, S., Yang, L., Zhang, C., Xiang, Y. T., Liu, Z., Hu, S., \& Zhang, B. (2020). Online mental health services in China during the COVID-19 outbreak. The Lancet Psychiatry, 7(4), e17-e18.

Lytvyn, V., Vysotska, V., Chyrun, L., \& Chyrun, L. (2016, August). Distance learning method for modern youth promotion and involvement in independent scientific researches. In 2016 IEEE First International Conference on Data Stream Mining E Processing (DSMP) (pp. 269-274). IEEE.

Menon, P., Nguyen, P. H., Saha, K. K., Khaled, A., Sanghvi, T., Baker, J., ... \& Rawat, R. (2016). Combining intensive counseling by frontline workers with a nationwide mass media campaign has large differential impacts on complementary feeding practices but not on child growth: results of a cluster-randomized program evaluation in Bangladesh. The Journal of Nutrition, 146(10), 2075-2084.

Ministry of Education. (2018). [Education Strategic Plan 2018-2022], available online: chromeextension://oemmndcbldboiebfnladdacbdfmadadm/http://www.unesco.org/new/fileadmin/MULTIMEDIA/ FIELD/Amman/pdf/ESP_English.pdf. Accessed $4^{\text {th }}$ July 2020

Mullen, P. R., Uwamahoro, O., Blount, A. J., \& Lambie, G. W. (2015). Development of counseling students' selfefficacy during preparation and training. The Professional Counselor, 5(1), 175-184.

Nassar, S. C., \& Singh, A. A. (2020). Embodying the multicultural and social justice counseling competency movement: Voices from the field. Journal of Counseling \& Development, 98(3), 253-26o.

Russell-Chapin, L. A. (2016). Integrating neurocounseling into the counseling profession: An introduction. Journal of Mental Health Counseling, 38(2), 93-102.

Siemens, G., Gašević, D., \& Dawson, S. (2015). Preparing for the digital university: A review of the history and current state of distance, blended, and online learning.

Simpson, O. (2018). Supporting students in online, open and distance learning. Routledge.

Skorikova, T. P., Khromova, S. S., \& Dneprovskaya, N. V. (2016). Distance Learning in Scientific and Professional Fields of Communication (Interdisciplinary Approach). International Journal of Environmental and Science Education, 11(10), 3467-3476.

Smith, A., \& Koltz, R. L. (2015). Supervision of School Counseling Students: A Focus on Personal Growth, Wellness, and Development. Journal of School Counseling, 13(2), n2.

Sung, C., Sánchez, J., Kuo, H. J., Wang, C. C., \& Leahy, M. J. (2015). Gender differences in vocational rehabilitation service predictors of successful competitive employment for transition-aged individuals with autism. Journal of Autism and developmental disorders, 45(10), 3204-3218. 
Sung, Y. T., Chao, T. Y., \& Tseng, F. L. (2016). Reexamining the relationship between test anxiety and learning achievement: An individual-differences perspective. Contemporary Educational Psychology, 46, 241-252.

Tarrasch, R. (2015). Mindfulness meditation training for graduate students in educational counseling and special education: A qualitative analysis. Journal of Child and family Studies, 24(5), 1322-1333.

Toquero, C. M. (2020). Challenges and opportunities for higher education amid the COVID-19 pandemic: The Philippine context. Pedagogical Research, 5(4).

Van Manen, M. (2016). Pedagogical tact: Knowing what to do when you don't know what to do. Routledge.

White, C. P., \& Levers, L. L. (2016). Parent-teacher engagement during child-centered pedagogical change in elementary school. Children \& Schools, 1-9.

Wilkinson, B. D., \& Hanna, F. J. (2016). New horizons in counselor pedagogy: The intersection of constructivist concepts and phenomenological awareness. The Journal of Humanistic Counseling, 55(1), 2-19.

World Health Organization. (2020). Coronavirus disease 2019 (COVID-19): situation report, 72.

Yamamoto, T. (2018). Developmental Support and Educational Counseling for Young Adults with Self-Injurious Behavior. Azabu University Journal, 30(15), 20.

Young, A., \& Bryan, J. (2015). The school counselor leadership survey: Instrument development and exploratory factor analysis. Professional School Counseling, 19(1), 1-15.

Zhu, P. (2018). Experiential growth group in counselor education: A review of its pedagogy, research, and ethical dilemmas. The Journal for Specialists in Group Work, 43(2), 144-165. 